УДК 656.212.5

\title{
ОБГРУНТУВАННЯ РАЦІОНАЛЬНОГО МІСЦЯ РОЗТАШУВАННЯ ЛОКОМОТИВНОГО ГОСПОДАРСТВА НА СОРТУВАЛЬНІЙ СТАНЦІї
}

\author{
Кандидати техн. наук М.Ю. Куценко, О.А. Дудін, інженери М.М. Дольова, О.В. Жовнір \\ ОБОСНОВАНИЕ РАЦИОНАЛЬНОГО МЕСТА РАСПОЛОЖЕНИЯ ЛОКОМОТИВНОГО \\ ХОЗЯЙСТВА НА СОРТИРОВОЧНОЙ СТАНЦИИ
}

\author{
Кандидаты техн. наук М.Ю. Куценко, А.А. Дудин, инженеры М.Н. Долгова, О.В. Жовнір
JUSTIFICATION RATIONAL LOCATION OF A LOCOMOTIVE DEPARTMENT IN MARSHALLING YARDS

\author{
Ph. D. M. Kutsenko, Ph. D. O. Dudin, engineers M. Dolgova, O. Zhovnir
}

Місие розташування локомотивного господарства суттєво впливає на експлуатаційні витрати, пов'язані з пробігом поїзних локомотивів від поїздів, що прибули в депо та вирушили назад з депо під поїзди, що відправляються. У роботі розглядаються основні випадки розміщення локомотивного господарства на односторонній та двосторонній сортувальній станції. 3 а побудованими графіками залежності сумарних пробігів локомотивів від частки вагонопотоку 3 переробкою зроблено висновки щодо ращіонального розташування локомотивного господарства на односторонній та двосторонній сортувальній станиії.

Ключові слова: сортувальна станція, сортувальна система, локомотивне господарство, пробіги локомотивів.

Место расположения локомотивного хозяйства существенно влияет на эксплуатационные расходы, связанные с пробегом поездных локомотивов от поездов, прибывших в депо и следовавших обратно из депо под отправляющиеся поезда. В работе рассматриваются основные случаи размещения локомотивного хозяйства на односторонней и двусторонней сортировочной станции. По построенным графикам зависимости суммарных пробегов локомотивов от доли вагонопотоков с переработкой сделаны выводы относительно рационального расположения локомотивного хозяйства на односторонней и двусторонней сортировочной станции.

Ключевые слова: сортировочная станция, сортировочная система, локомотивное хозяйство, пробеги локомотивов.

Marshalling yards, play a crucial role in the development of transport on railway transport. They provide the most difficult part of working-processing and formation of technical routes. Stability of transportation process in many areas and sites of the railway network is dependent on the successful work of marshalling yards.

Location of the locomotive department significantly affects the operational costs associated with mileage of train locomotives from trains arriving at the depot and back from the depot under the departing train.

This article discusses the options for the placement of a locomotive department on a unilateral or bilateral marshalling yard. Used dependency graphs based on total runs of locomotives from the proportion of working with processing, conclusions are made on the rational location of the locomotive department at the unilateral and bilateral marshalling yard.

The locomotive department on the unilateral marshalling yard advisable to place next to the park administration to reduce runs of the exchangeable train locomotive and reducing the width of the marshalling yard. After the construction of the second sorting system it is advisable to arrange the station complex equipping additional devices between the parks reception and departure in the opposite end of the station.

Keywords: marshalling yard, sorting system, locomotive department, running of locomotives. 
Вступ. У даний час відбувається реформування залізничного транспорту, метою якого $є$ підвищення якості надаваних послуг при безпечній та ефективній організації виробничого процесу [1]. Розміщення локомотивного господарства (ЛГ) на сортувальних станціях суттєво впливає на експлуатаційні витрати, пов'язані 3 пробігом поїзних локомотивів від поїздів, що прибули в депо та вирушили назад 3 депо під поїзди, що відправляються.

Постановка проблеми. Розміщення ЛГ повинно бути ув'язано із загальною схемою розвитку станції як на першу чергу, так і на перспективу, та забезпечувати зручну подачу локомотивів до составів та їх прибирання при найменшій кількості пересічень 3 маршрутами прямування організованих поїздів та маневрових переміщень. ЛГ бажано розміщувати поблизу тих приймально-відправних парків, де очікується найбільше прибуття та відправлення поїздів. У сортувальній системі з послідовним розміщенням парків ЛГ можна розташовувати паралельно будь-якому 3 парків: сортувальному, приймання або відправлення.

В ТУПС-48 [2] та ТУПС-54 [3] ЛГ на односторонніх та двосторонніх станціях рекомендувалося розміщувати поруч 3 парком приймання переважного напрямку. В ТУПС-61 [4] рекомендувалася схема 3 розміщенням ЛГ поруч із сортувальним парком, між ним та головними коліями невантажного (протилежного напрямку сортування) напрямку. У залежності від місцевих умов при відповідному обгрунтуванні допускалося розміщення ЛГ у районі парку відправлення поїздів, а в окремих випадках - поруч з парком прибуття 3 облаштуванням екіпірування поїзних локомотивів у районі хвостової горловини сортувального парку.

З 1978 року Інструкцією з проектування станцій та вузлів (ІПСВ-78) [5] ЛГ на односторонніх сортувальних станціях з гірками великої та середньої потужності рекомендується розміщувати паралельно парку приймання, а 3 гірками підвищеної потужності - паралельно сортувальному парку.

Окрім цих випадків розміщення ЛГ між системами парків, зустрічаються випадки бокового або зовнішнього розміщення ЛГ. Зовнішне розміщення ЛГ має ряд експлуатаційних незручностей (багато пересічень маршрутів), здебільшого викликає необхідність спорудження дорогих шляхопроводів і тому при будівництві нових сортувальних станцій не застосовується.

Основна частина. $\mathrm{y}$ статті розглядаються три основні випадки розміщення локомотивного господарства на односторонній сортувальній станції: I варіант - паралельно сортувальному парку (рис. 1), II варіант паралельно парку приймання (рис. 2) і III варіант - паралельно парку відправлення (рис. 3). При цьому парки для транзитних поїздів передбачалися поруч із об’єднаним парком відправлення.

Згідно 3 [6] пробіг локомотивів на один поїзд у першому варіанті (див. рис. 1) складе:

- для непарних поїздів 3 переробкою

$$
l_{m p 3 / n}^{\text {нen }}=l_{\text {вux }}^{n}+l_{H}+l_{\text {вx }}^{c}+l_{\text {вux }}^{c}+l_{\text {s }}+l_{\text {вx }}^{\text {sid }}+l_{0}+2 \cdot l_{\text {вux }}^{\text {sid }}
$$

- парних поїздів з переробкою

$$
l_{m p 3 / n}^{\text {nарн }}=2 \cdot l_{B x}^{n}+l_{0}+l_{\text {вux }}^{n}+l_{H}+l_{B x}^{c}+l_{\text {вux }}^{c}+l_{B}+l_{B x}^{\text {вid }} ;
$$

- транзитних непарних поїздів

$$
l_{m p}^{H e n}=4 \cdot l_{\text {sux }}^{\text {sid }}+2 \cdot l_{0}+2 \cdot l_{\text {si }}^{\text {sid }}+2 \cdot l_{s}+2 \cdot l_{\text {sux }}^{c}+l_{c} ;
$$

- транзитних парних поїздів

$$
l_{m p}^{n a p h}=2 \cdot l_{\text {sid }}^{\text {sid }}+2 \cdot l_{B}+2 \cdot l_{\text {sux }}^{c}+l_{c} .
$$




\section{Експлуатація залізниць}

Перевага розміщення ЛГ поруч із сортувальним парком полягає у поточності пропуску локомотивів поїздів 3 переробкою обох напрямків. Недоліком цього варіанта $\epsilon$ необхідність великої ширини станційної площадки, оскільки локомотивне та вагонне господарство розміщуються поруч із сортувальним парком. Та якщо надалі передбачати будівництво другої сортувальної систем, то це значно збільшить потрібну ширину станційної площадки у порівнянні 3 іншими варіантами.

Пробіг локомотивів у розрахунку на один поїзд при розташуванні ЛГ поруч 3 парком приймання (рис. 2) буде:

- для непарних поїздів 3 переробкою

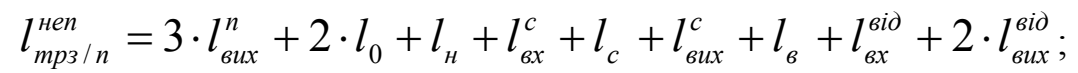

- парних поїздів з переробкою

$$
l_{m p 3 / n}^{n a p h}=2 \cdot l_{B x}^{n}+l_{B u x}^{n}+l_{H}+l_{B x}^{c}+l_{c}+l_{\text {вux }}^{c}+l_{B}+l_{B x}^{\text {sid }} ;
$$

- транзитних непарних поїздів

$$
l_{m p}^{\text {нen }}=4 \cdot l_{\text {sux }}^{\text {sid }}+3 \cdot l_{0}+2 \cdot l_{\text {sx }}^{\text {sid }}+2 \cdot l_{\text {s }}+2 \cdot l_{\text {sux }}^{c}+2 \cdot l_{c}+2 \cdot l_{b x}^{c}+2 \cdot l_{H}+2 \cdot l_{\text {sux }}^{c} \text {; }
$$

- транзитних парних поїздів

$$
l_{m p}^{\text {парн }}=2 \cdot l_{\text {вx }}^{\text {sid }}+2 \cdot l_{\text {s }}+2 \cdot l_{\text {вux }}^{c}+2 \cdot l_{c}+2 \cdot l_{\text {sx }}^{c}+2 \cdot l_{H}+2 \cdot l_{\text {вux }}^{n}+l_{0} .
$$

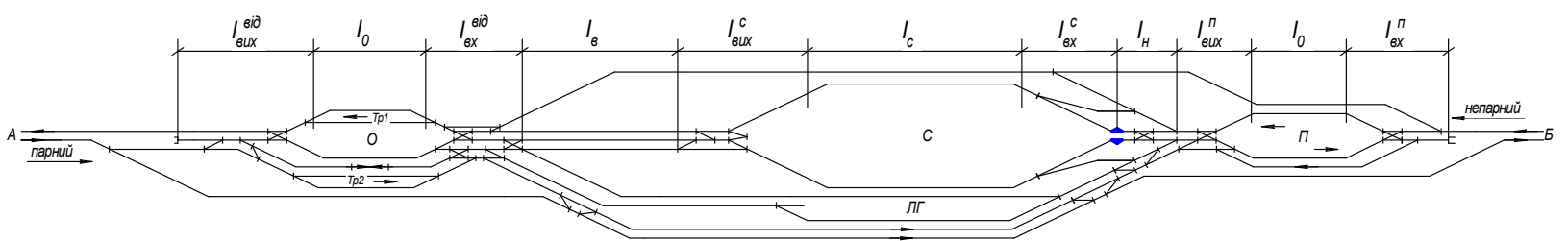

Рис. 1. Схема односторонньої сортувальної станції з розташуванням ЛГ поруч із сортувальним парком

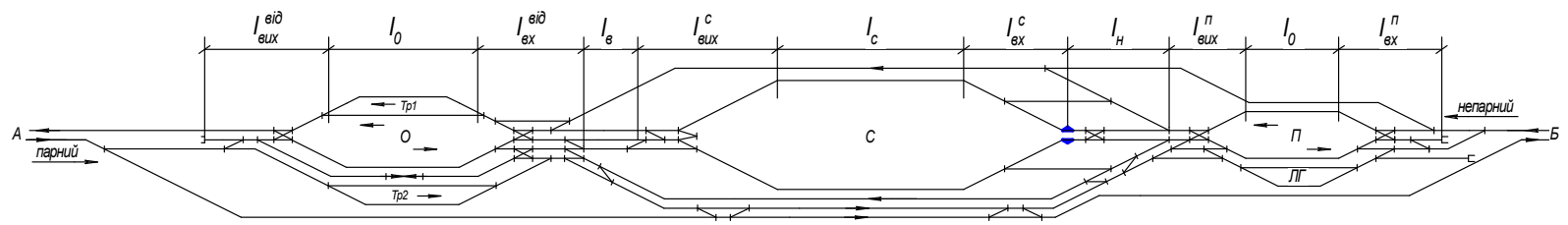

Рис. 2. Схема односторонньої сортувальної станції з розташуванням ЛГ поруч з парком приймання

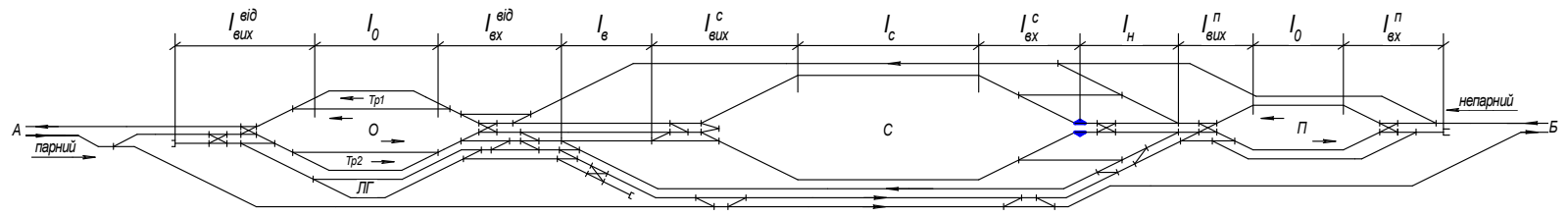

Рис. 3. Схема односторонньої сортувальної станції з розташуванням ЛГ поруч з парком відправлення 


\section{Експлуатація залізниць}

У другому варіанті потрібна ширина станційної площадки зменшується, скорочується пробіг у депо поїзних локомотивів від поїздів, які надійшли в переробку, проте при цьому зростає пробіг поїзних локомотивів 3 депо під состави поїздів свого формування та особливо локомотивів

$$
l_{m p 3 / n}^{\text {нen }}=l_{\text {вux }}^{n}+l_{H}+l_{\text {sx }}^{c}+l_{c}+l_{\text {вux }}^{c}+l_{B}+l_{\text {вx }}^{\text {sid }}+2 \cdot l_{\text {вux }}^{\text {gid }} ;
$$

- парних поїздів 3 переробкою

$$
l_{m p 3 / n}^{\text {napн }}=2 \cdot l_{B x}^{n}+2 \cdot l_{0}+l_{\text {вux }}^{n}+l_{H}+l_{B x}^{c}+l_{c}+l_{\text {вux }}^{c}+l_{B}+l_{B x}^{\text {sid }} ;
$$

- транзитних непарних поїздів

$$
l_{m p}^{\text {нen }}=2 \cdot l_{\text {вux }}^{\text {вid }}+l_{0}
$$

- транзитних парних поїздів

$$
l_{m p}^{n a p h}=2 \cdot l_{B x}^{\text {sid }}+l_{0} .
$$

У третьому варіанті порівняно 3 першим та другим значно збільшуються пробіги локомотивів від поїздів, які прибули у розформування, але набагато менший пробіг локомотивів від транзитних поїздів у депо, а також пробіг усіх поїзних локомотивів під состави поїздів, які відправляються. У цьому варіанті, так як i у другому, зменшується необхідна ширина станційної площадки та створюються кращі умови для розвитку станції в класичну двосторонню станцію.

Варіант, у якому приймально-відправні парки для транзитних поїздів розміщувалися б паралельно парку приймання, не розглядався, так як це викликало б збільшення експлуатаційних витрат на утримання пунктів технічного обслуговування вагонів. При цьому припускалося, що станційна площадка достатня для спорудження станцій за будь-яким 3 розглянутих варіантів.

Надалі у статті розглянуто пробіги локомотивів після спорудження другої сортувальної системи та при всіх розглянутих схемах односторонньої станції (рис. 4-6).

Пробіг локомотивів при розташуванні локомотивного господарства паралельно сортувальному парку (див. варіант IV, рис. 4) буде:

- для непарних поїздів з переробкою

$$
l_{m p 3 / n}^{\text {Hen }}=l_{\text {вux }}^{n}+l_{H}+l_{B x}^{c}+l_{\text {вux }}^{c}+l_{B}+l_{B x}^{\text {sid }}+l_{0}+2 \cdot l_{\text {вux }}^{\text {sid }} ;
$$

- парних поїздів з переробкою

$$
l_{\text {mрз } / n}^{n а р н}=l_{\text {вих }}^{n}+2 \cdot l_{c \partial в}+l_{в}+l_{0}+2 \cdot l_{\text {вих }}^{\text {від }} ;
$$

- транзитних непарних поїздів

$$
l_{m p}^{\text {Hen }}=4 \cdot l_{\text {sux }}^{\text {sid }}+2 \cdot l_{0}+2 \cdot l_{\text {si }}^{\text {sid }}+2 \cdot l_{B}+2 \cdot l_{\text {sux }}^{c}+l_{c} ;
$$

- транзитних парних поїздів

$$
l_{m p}^{\text {naph }}=4 \cdot l_{\text {вux }}^{\text {sid }}+2 \cdot l_{c \partial в}+l_{0} .
$$




\section{Експлуатація залізниць}

У варіанті V (рис 5) пробіг локомотивів буде дорівнювати:

- для непарних поїздів 3 переробкою

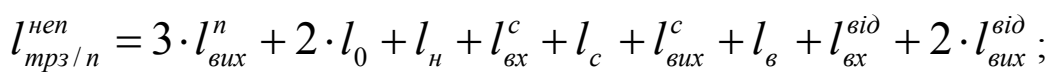

- парних поїздів з переробкою

$$
l_{m p 3 / n}^{\text {парн }}=2 \cdot l_{\text {вux }}^{n}+2 \cdot l_{c \partial в}+l_{B}+l_{\text {виx }}^{c}+l_{c}+l_{B x}^{c}+l_{H}+2 \cdot l_{B x}^{n}+l_{\text {вux }}^{\text {sid }} \text {; }
$$

- транзитних непарних поїздів

$$
l_{m p}^{\text {нen }}=4 \cdot l_{\text {вux }}^{\text {sid }}+3 \cdot l_{0}+2 \cdot l_{\text {вx }}^{\text {sid }}+2 \cdot l_{\text {s }}+2 \cdot l_{\text {вux }}^{c}+2 \cdot l_{c}+2 \cdot l_{\text {six }}^{c}+2 \cdot l_{\mu}+2 \cdot l_{\text {вux }}^{c}
$$

- транзитних парних поїздів

$$
l_{m p}^{\text {napн }}=2 \cdot l_{\text {вих }}^{\text {вid }}+2 \cdot l_{c \partial \beta}+2 \cdot l_{B x}^{n}+l_{0} .
$$

I в останньому варіанті, де ЛГ розташоване поруч $з$ парком відправлення непарної системи (рис. 6), пробіг локомотивів буде дорівнювати:

- для непарних поїздів з переробкою

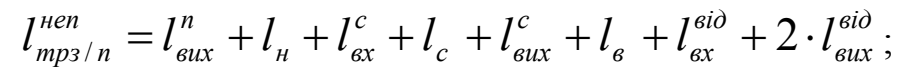

- парних поїздів з переробкою

$$
l_{m p 3 / n}^{n a p H}=l_{\text {sux }}^{n}+2 \cdot l_{0}+3 \cdot l_{\text {sid }}^{\text {sid }}+2 \cdot l_{B}+l_{\text {sux }}^{c}+l_{c}+l_{\text {sx }}^{c}+2 \cdot l_{\text {sux }}^{\text {sid }}
$$

- транзитних непарних поїздів

$$
l_{m p}^{\text {Hen }}=2 \cdot l_{\text {Bux }}^{\text {sid }}+l_{0}
$$

- транзитних парних поїздів

$$
l_{m p}^{n a p н}=4 \cdot l_{\text {sid }}^{\text {sid }}+4 \cdot l_{\text {s }}+2 \cdot l_{\text {вux }}^{c}+2 \cdot l_{c}+2 \cdot l_{\text {вx }}^{c}-2 \cdot l_{c \partial \theta}+4 \cdot l_{\text {вux }}^{\text {sid }}+3 \cdot l_{0} .
$$

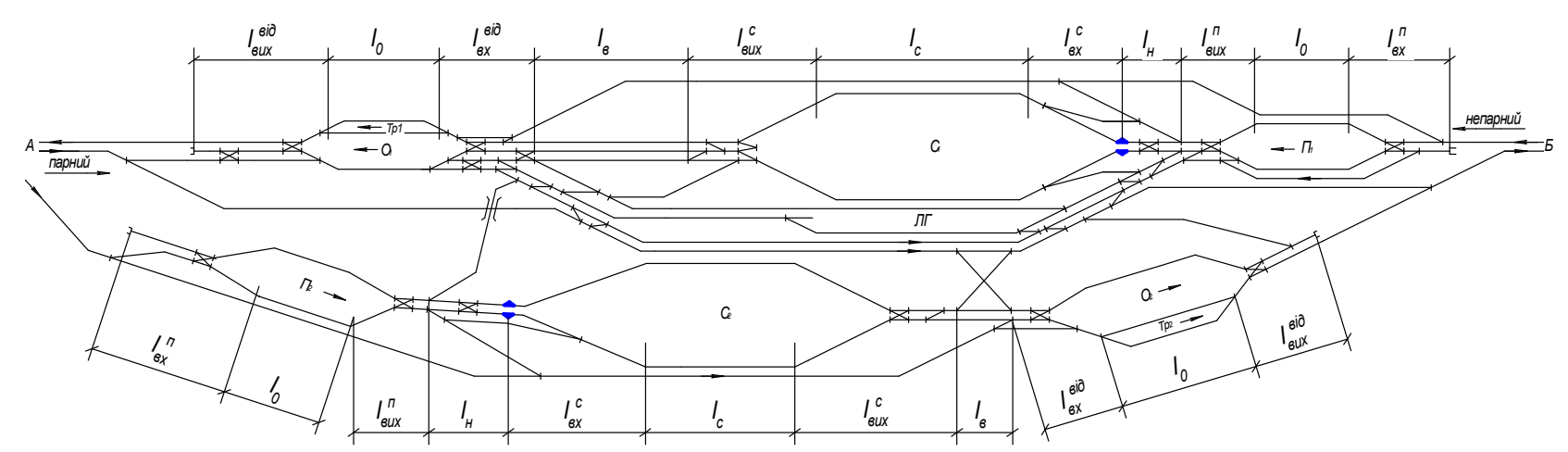

Рис. 4. Схема двосторонньої станції з розташуванням ЛГ поруч із сортувальним парком 


\section{Експлуатація залізниць}

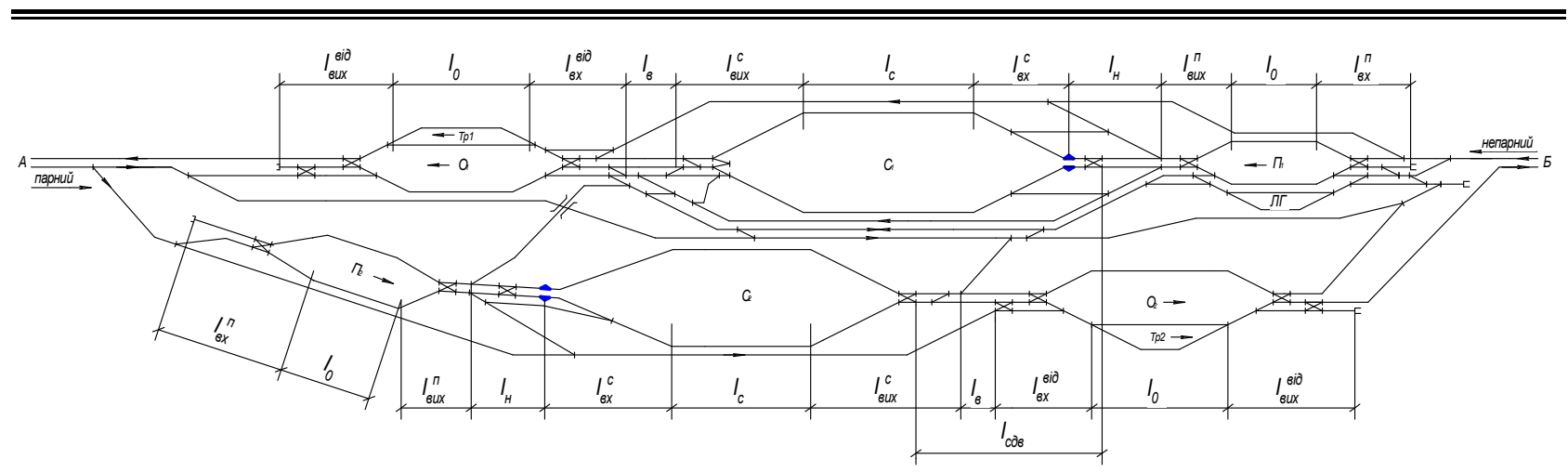

Рис. 5. Схема двосторонньої станції з розташуванням ЛГ поруч з парком приймання

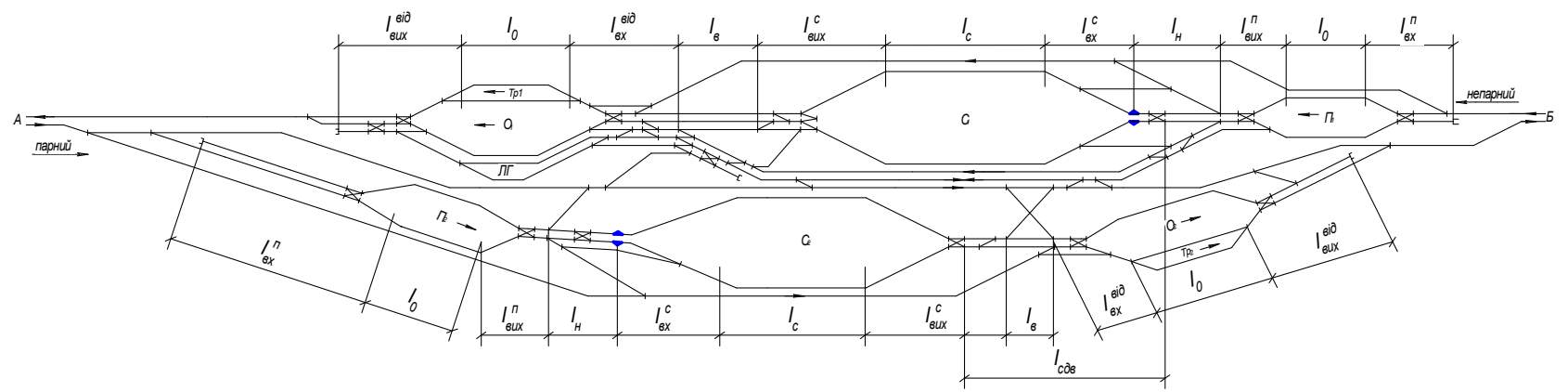

Рис. 6. Схема двосторонньої станції з розташуванням ЛГ поруч з парком відправлення

Для визначення сфер застосування вказаних шести варіантів частина вагонопотоку 3 переробкою, який надходить на сортувальну станцію, варіювалася від 50 до $80 \%$. Норма корисної довжини приймально-відправних колій приймалася рівною 1050 м. Довжини горловин парків та пробіги поїзних локомотивів визначались за масштабними планами станції за варіантами. Порівняння варіантів були виконані шляхом зіставлення пробігів поїзних локомотивів від поїздів у депо та назад під поїзди, що відправляються. Окремо розраховувався пробіг для односторонніх сортувальних станцій та для двосторонніх. Пробіги локомотивів, які припадають на один поїзд, зведені у таблицю.

За результатами розрахунків побудований графік залежності сумарних пробігів від частки вагонопотоку 3 переробкою, який наведений на рис. 7. Як видно з графіка, при будівництві односторонньої станції та частці потоку з переробкою менше 70 \% локомотивне господарство доцільніше розміщувати поруч із парком відправлення (варіант III).

Таблиця

Пробіги локомотивів, що припадають на один поїзд

\begin{tabular}{|l|c|c|c|c|c|c|}
\hline \multirow{2}{*}{\multicolumn{1}{|c|}{ Категорії поїздів }} & \multicolumn{5}{|c|}{ Пробіг на один поїзд, км, за варіантами } \\
\cline { 2 - 7 } & \multicolumn{3}{|c|}{ Одностороння } & \multicolumn{3}{c|}{ Двостороння } \\
\cline { 2 - 7 } & I & II & III & IV & V & VI \\
\hline Непарні з переробкою & 4,70 & 8,30 & 4,70 & 4,70 & 8,30 & 4,67 \\
\hline Парні з переробкою & 4,30 & 4,60 & 7,40 & 5,00 & 6,00 & 8,00 \\
\hline Непарні транзитні & 9,50 & 14,00 & 3,40 & 9,50 & 14,00 & 3,40 \\
\hline Парні транзитні & 3,80 & 9,60 & 2,60 & 4,50 & 4,90 & 10,80 \\
\hline
\end{tabular}

При перебудові цієї станції у двосторонню (варіант VI) при цьому ж відсотку поїздів 3 переробкою пробіг локомотивів зростає. При зміні частки поїздів з переробкою на двосторонній станції пробіг локомотивів залишається приблизно на одному рівні у 
зв’язку з тим, що пробіг від транзитних поїздів приблизно дорівнює сумарному пробігу від поїздів з переробкою. Як видно 3 графіка, розміщення локомотивного господарства на двосторонній станції поруч із парком відправлення практично не залежить від частки потоку з переробкою.

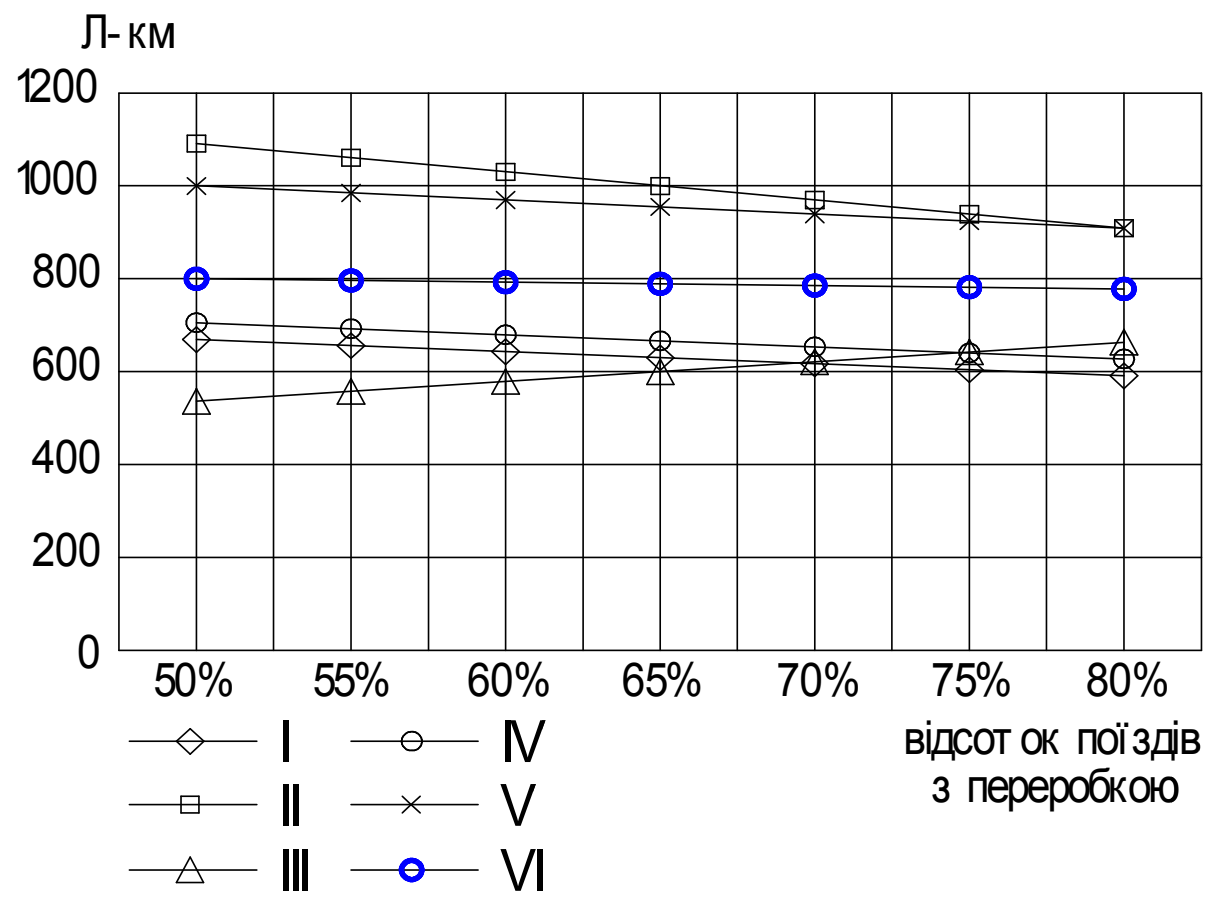

Рис. 7. Графік залежності сумарних пробігів локомотивів від частки вагонопотоку з переробкою

Згідно $з$ пробігами поїзних локомотивів будівництво ЛГ паралельно сортувальному парку на односторонній станції вигідно при відсотку поїздів з переробкою 70 \% та більше. При будівництві другої сортувальної системи пробіг усіх локомотивів збільшиться несуттєво.

Проведене дослідження показало, що розміщення ЛГ при гірках великої та середньої потужності поруч із парком приймання $\epsilon$ невигідним, так як сумарний пробіг від усіх поїздів значно вищий, ніж в інших варіантах. Це пов'язано 3 тим, що локомотиви від транзитних поїздів без переробки змушені прямувати в депо та назад через усю станцію. Розміщення ЛГ поруч 3 парком приймання може виявитися прийнятним тільки після будівництва другої сортувальної системи. Для односторонніх сортувальних станцій при наявності достатньої станційної площадки доцільно розглядати два конкурентоспроможних варіанти розміщення ЛГ - поруч із сортувальним парком або 3 парком відправлення. Вибір того чи іншого варіанта повинен бути підтверджений технікоекономічними розрахунками та буде залежати від частки поїздів 3 переробкою та місцевих умов, які визначаються капітальними витратами за цими варіантами.

Висновки. Для зменшення пробігів поїзних локомотивів, що змінюються, i скорочення ширини станційної площадки ЛГ на односторонній сортувальній станції доцільно розміщувати поруч 3 парком відправлення, а після спорудження другої сортувальної системи улаштовувати між парками приймання i відправлення у протилежному кінці станції додатковий комплекс екіпірувальних пристроїв. 


\section{Список використаних джерел}

1. Транспортна стратегія України на період до 2020 року [Електронний ресурс]: схвалена розпорядженням Кабінету Міністрів України від 16 грудня 2009 р. №1555-р. - Режим доступу: www/URL: http://www.mintrans.gov.ua/ uk/discussion/15621.html/ 10.12.2009. - Загол. з екрана.

2. Технические указания по проектированию станций и узлов [Текст]. - М.: Трансжелдориздат, 1948. $-124 \mathrm{c}$.

3. Технические указания по проектированию станций и узлов на железных дорогах нормальной колеи [Текст]. - М.: Трансжелдориздат, 1954. -120 с.

4. Технические указания по проектированию станций и узлов на железных дорогах общей сети Союза ССР [Текст]: ВСП 56-61. - М.: Трансжелдориздат, 1961. - 151 с.

5. Инструкция по проектированию станций и узлов на железных дорогах Союза ССР [Текст]: ВСН 56-78. - М.: Транспорт, 1978. - 171 с.

6. Олейникова, Л. А. Сферы применения односторонних и двусторонних сортировочных станций при росте и спаде объемов переработки вагонов [Текст] : дис... канд. техн. наук : 05.22 .08 / Олейникова Людмила Алексеевна. - С.Пб., 2006. - 198 с.

7. Архангельский, Е. В. Выбор этапного развития станций [Текст] / Е.В. Архангельский // Повышение эффективности использования технических средств на железнодорожных станциях: труды ВНИИЖТа. - М.: Транспорт, 1986. - С. 3-18.

8. Болотный, В.Я. Совершенствование схем и технологии работы железнодорожных станций [Текст]: учебное пособие для вузов / В.Я. Болотный. - М.: Транспорт, 1986. - 280 с.

9. Логвинов, С.И. Определение ориентировочной стоимости строительства железнодорожных станций и узлов по укрупненным показателям [Текст] / С. И. Логвинов, Ю. И. Єфименко. - Л.: ЛИИЖТ, 1990. - 30 с.

10. Федотова, Т. Н. Развитие односторонних сортировочных станций [Текст] / Т. Н. Федотова // Вопросы развития железнодорожных станций и узлов: межвуз. сб. науч. статей. - Гомель: БелИИЖТ, 1981. - C. 39-52.

Рецензент д-р техн. наук Є.С. Альошинський

Куценко Максим Юрійович, канд. техн. наук, доцент кафедри залізничних станцій та вузлів Українського державного університету залізничного транспорту. Тел.: (057) 730-10-42 E-mail: maksimus84@meta.ua. Дудін Олексій Аркадійович, канд. техн. наук, доцент кафедри колії та колійного господарства Українського державного університету залізничного транспорту. Тел.: (057) 730-10-42.

Долгова Марія Миколаївна, студентка магістратури НН ІППК Українського державного університету залізничного транспорту Тел.: (057) 730-10-42.

Жовнір Оксана Василівна, студентка магістратури НН ІППК Українського державного університету залізничного транспорту Тел.: (057) 730-10-42.

Kutsenko Maxim Yriyovich Ph. D., associate professor department of train stations and nodes Ukrainian State University of Railway Transport. Tel.: (057) 730-10-42 E-mail: maksimus84@meta.ua.

Dudin Olexiy Arkadiyovich Ph. D., associate professor department of track and railroad facilities Ukrainian State University of Railway Transport. Tel.: (057) 730-10-42.

Dolgova Maria Mykolaivna graduate student NN IPPK Ukrainian State University of Railway Transport. Tel.: (057) 730-10-42.

Zhovnir Oksana Vasylivna graduate student NN IPPK Ukrainian State University of Railway Transport. Tel.: (057) $730-10-42$.

Стаття прийнята 01.07.2015 p. 